\title{
A New Phosphate Selective Electrode and Its Application in Some Foods
}

\author{
Sukru Kalayci \\ Gazi University, Vocational School of Technical Sciences, Department of chemistry, Ankara, Turkey \\ E-mail: skalayci@gazi.edu.tr
}

Received: 29 April 2021 / Accepted: 13 June 2021 / Published: 10 August 2021

\begin{abstract}
A highly sensitive phosphate selective electrode (ISE) was fabricated using $\mathrm{Ba}_{3} \mathrm{PO}_{4}, \mathrm{Cu}_{2} \mathrm{~S}$ and $\mathrm{Ag}_{2} \mathrm{~S}$ solids. The highest sensitivity of ISE was obtained with $20 \% \mathrm{Ba}_{3} \mathrm{PO}_{4}(\mathrm{~m} / \mathrm{m})$ composition. The ISE shows a slope of about $57 \mathrm{mV}$ towards the phosphate ion in the concentration range $1 \times 10^{-1} \mathrm{M}-1 \times 10^{-6} \mathrm{M}$. The ISE characterization was performed. The ISE was judged to be accurate in the presence of possible interfering ions. The amount of phosphate in foods was measured as real sample analysis and the proposed ISE was accepted as a reliable, sensitive and easy-to-make sensor device for phosphate analysis in food samples.
\end{abstract}

Keywords: Ion selective electrode, Phosphate, Determination, Food sample

\section{$\underline{\text { FULL TEXT }}$}

(C) 2021 The Authors. Published by ESG (www.electrochemsci.org). This article is an open access article distributed under the terms and conditions of the Creative Commons Attribution license (http://creativecommons.org/licenses/by/4.0/). 